\title{
DETERMINING THE EFFICIENCY OF MASS TRAPPING OF YELLOW STICKY TRAPS IN DIFFERENT WAVELENGTHS AGAINS PISTACHIO PSYLLID IN SIIRT PROVINCE
} [Agonescena pistaciae Burc. and Laut. (Hemiptera: Psyllidae)]

\author{
İnanç Özgen ${ }^{1 *}$, Halil Bolu², Tarkan Ayaz ${ }^{3}$ İbrahim Koçç, Çetin Mutlu ${ }^{5}$, Ayçin Aksu Altun ${ }^{6}$ \\ ${ }^{1}$ Firat University, Engineering Faculty, Bioengineering Department, Turkey \\ ${ }^{2}$ Dicle University, Agricultural Faculty, Plant Protection Department, Turkey \\ ${ }^{3}$ Şırnak University, Agricultural Faculty, Plant Protection Department, Turkey \\ ${ }^{4}$ Bitlis Eren University, Faculty of Engineering and Architecture, Environmental Engineering Department, Turkey \\ ${ }^{5}$ Harran University, Agricultural Faculty, Plant Protection Department, Turkey \\ ${ }^{6}$ GAP Agricultural Research Institute, Turkey
}

\begin{abstract}
Original scientific paper This study was conducted in gardens infested with pistachio psylla in Siirt Province between 2007 and 2010. It was detected that pistachio psylla forms were the highest populations in the pistachio gardens in the Central District of Siirt Province. It causes important damages particularly on young leaves in mid-June and in the maturing period of fruits in mid- and late-August. The yellow sticky trap coded $1016 \mathrm{~B}$ was found to be more effective than other coded traps. It was concluded that these traps were important for decreasing of the population of the pest in cases where the population is low. It was found that traps provided positive contribution if combined with other control methods. One of the best promising results was gathered when used in 4 traps for each tree and 7-day periods of hanging
\end{abstract}

Keywords: Agonescena pistaciae, Population, Trap Numbers, IPM

\section{Introduction}

One of the most important problems in the production of Pistachio is related to protection of the plant against pest insects. Pistachio psylla Agonescena pistaciae Burchardt \& Lauterer,1989 (Hemiptera: Psyllidae) is among the most important species as regards the economy (Altin et al., 1992; Altın et al., 1996; Bolu, 2002). Chemicals are used in general against the pistachio psylla, A. pistaciae, and use of chemical at wrong times and wrong dosages create negative results on the agroecosystem. Conventional methods used against the pistachio psylla, which cause significant economic losses in pistachio cultivation lands in the Southeastern Anatolia Region in Turkey, are not sufficient per se to remove the pest problem. One of the principle trends of the pests for is to use light and color traps as a method of combat against pests. This method is also useful to determine the timing for control of pests. In general, yellow-colored traps are used to make the insects for mass trapping. Furthermore, they are used both as a direct and indirect fighting method (Öncüer, 2000). It was reported that in addition to the high reflection values of the yellow color, yellow-colored objects create higher-thannormal stimulations on insects, in other words, all the phytophage insects are attracted by the yellow color. Together with the high reflection amounts of the yellow color, it was also reported that yellow objects attract insects in levels higher than normal, in other words, all the phytophage insects are attracted with the yellow color (Hirato and Kato, 2011).

Again, some other investigators have used yellow sticky traps to determine the density of adult population of pistachio psylla and its reproduction rate. It has been concluded that yellow adhesive traps were important for seasonal population studies (Hadiyan and Seyedoleslami, 2001). In their study, they determined the efficiency of yellow adhesive traps with different RAL codes and, Özgen et al. (2013) used yellow sticky traps in 8 different tones, and determined that code 1016 attracted psylla adults more and among the variations of the yellow color, code. This study was implemented with the purpose of determining the efficiency of attraction of psylla in populations with different adult densities by code $1016 \mathrm{~B}$ with high attraction power.

\section{Material and Method}

\subsection{Material}

The main materials of the study consisted of pistachio trees in Siirt Province, A. pistaciae, yellow sticky traps in different wavelengths, japenese umbrella, ice cups, Petri dishes in different sizes, and similar.

\subsection{Method}


In the follow-up of the population of the pest, 10 compound leaves were collected from in different directions from each tree in each garden starting with the foliation of tress, periods of adulthood, nymph and egg periods of the pest were traced. Follow-up of populations of the natural enemies of the pest in sampling gardens was carried out by making the beneficial insects onto the japenese umbrella by hitting the trees on four sides; and also, natural enemy species were counted by capturing on yellow adhesive traps. After counting and releasing the known insect species dropping onto the japenese umbrella, other insects were taken into the killing bottle; when these insects were thus killed, they were taken into Petri dishes containing blotting paper, and were brough to the laboratory. The following methods were applied as of the years of the study. As mentioned in the methods section, 10 compound leaves were collected from each tree in each garden starting from the time of emerging of the pest in nature, and adult, nymph and egg stages of the pest were followed on 100 leaves in total. These procedures were carried out using loops with the purpose of not decreasing the pest population, through collection of leaves. In total, 50 yellow adhesive traps were hanged on 20 trees in total (1 trap on 5 trees, 2 traps on 5 trees, 3 traps on 5 trees, and 4 traps on 5 trees) in this period with the purpose of reducing the pest population. Furthermore, 3 trees were left without traps for comparison. Traps were counted with weekly intervals and adult individuals were recorded.

\section{Results}

In previously study; The yellow sticky trap coded 1016 B was found to be more effective than other coded traps (Özgen et al., 2013).Because of the trap coded 1016 was found statistically more effective as compared to the other traps, in this study a trial was set based on the lightening of color on the trap coded 1016, and following the application, and results on days 1, 4 and 7 are shown in Figures 1, 2 and 3. Upon statistical examination of the study results, it was seen that trap coded 1016 B differed from the group of other traps, and captured the greatest number of adult individuals (Table 1). When the numbers of adult individuals captured in traps were considered as regards days, it was seen that days 1,4 and 7 constituted different groups, and the traps that captured the greatest numbers of adult individuals were those counted in day 7 (Table 2).

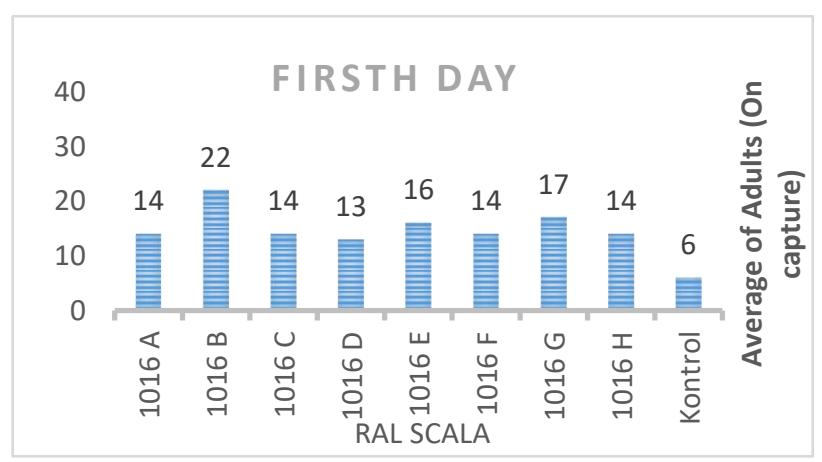

Figure 1. Determination of different 1016 codes capture activities on the $1^{\text {st }}$ day of application.

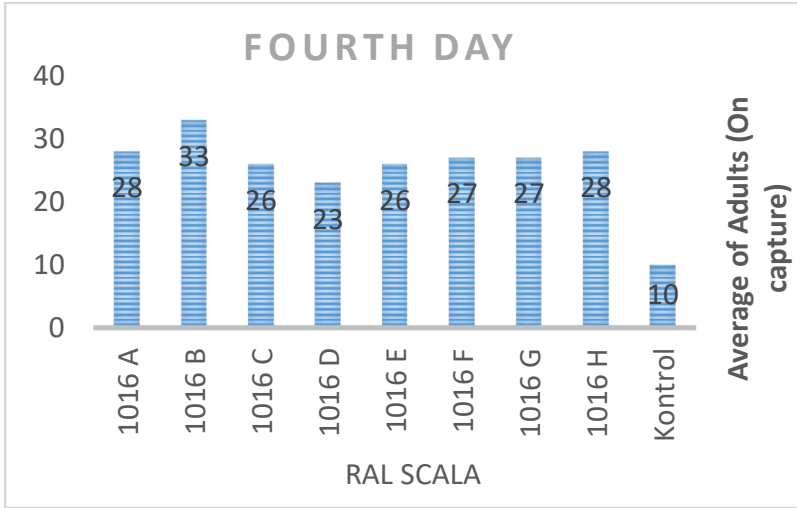

Figure 2. Determination of different 1016 codes capture activities on the $4^{\text {th }}$ day of application.

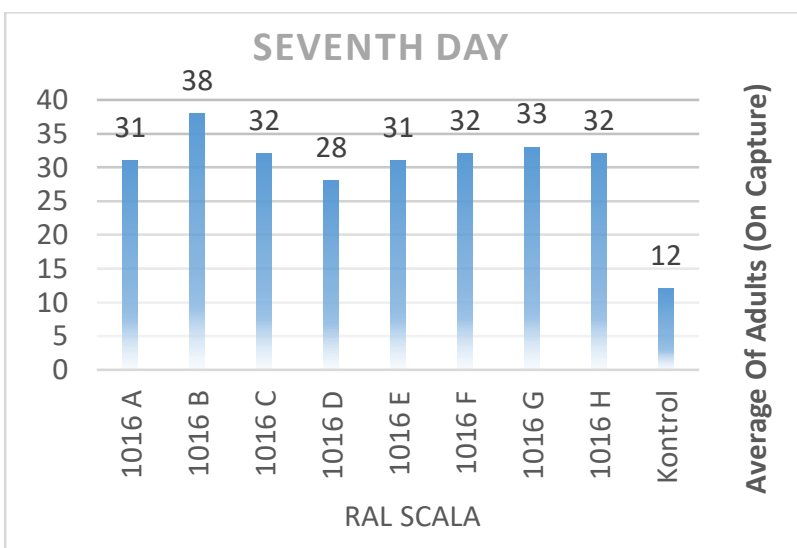

Figure 3. Determination of different 1016 codes capture activities on the $7^{\text {th }}$ day of application.

Table 1. Statistical evaluation of different versions of trap 1016.

\begin{tabular}{lrrrr}
\hline Level & & & & Least Sq Mean \\
\hline 1016 B & A & & & 31,000000 \\
1016 G & & B & & 25,666667 \\
1016 H & & B & C & 24,666667 \\
1016 A & B & C & 24,333333 \\
1016 E & B & C & 24,333333 \\
1016 F & B & C & 24,333333 \\
1016 C & B & C & 24,000000 \\
1016 D & & C & 21,333333 \\
Control & & & D & 9,333333
\end{tabular}

Table 2. Averages of adult individuals captured with traps on different days.

\begin{tabular}{lrrrr}
\hline Level & & & & Least Sq Mean \\
\hline 7 & A & & & 29,888889 \\
4 & & B & & 25,333333 \\
1 & & & C & 14,444444
\end{tabular}


3.1 Efficiency of Sticky Traps in Different Numbers (1, 3 and 4) on the Numbers of Adults and Nymphs in Two Different Population Densities

After determining the most suitable tone of yellow and hanging height, trap coded $1016 \mathrm{~B}$ was hanged on trees in different numbers (1 trap, 3 traps, and 4 traps), and differences between the numbers of adult individuals captured in traps and the effects of these numbers of nymphs on trees were determined.

\subsection{Effects of Trap Numbers on the Psylla Adult Population} on Two Different Population Densities (A and B) in Different Days

\section{a. Population A}

According to individual counts, the adult population was in the range of $\mathbf{2 6}$ and $\mathbf{3 8}$. Numbers of adult individuals captured with trap numbers of 1,3 and 4 are shown in Figures 4, 5 and 6.

\section{b. Population B}

It was found in the counts that the adult population was in the range of $\mathbf{3 8}$ and $\mathbf{4 6}$, and study was carried out on this population. Numbers of adult individuals captured with trap numbers of 1, 3 and 4 are shown in Figures 7, 8 and 9.

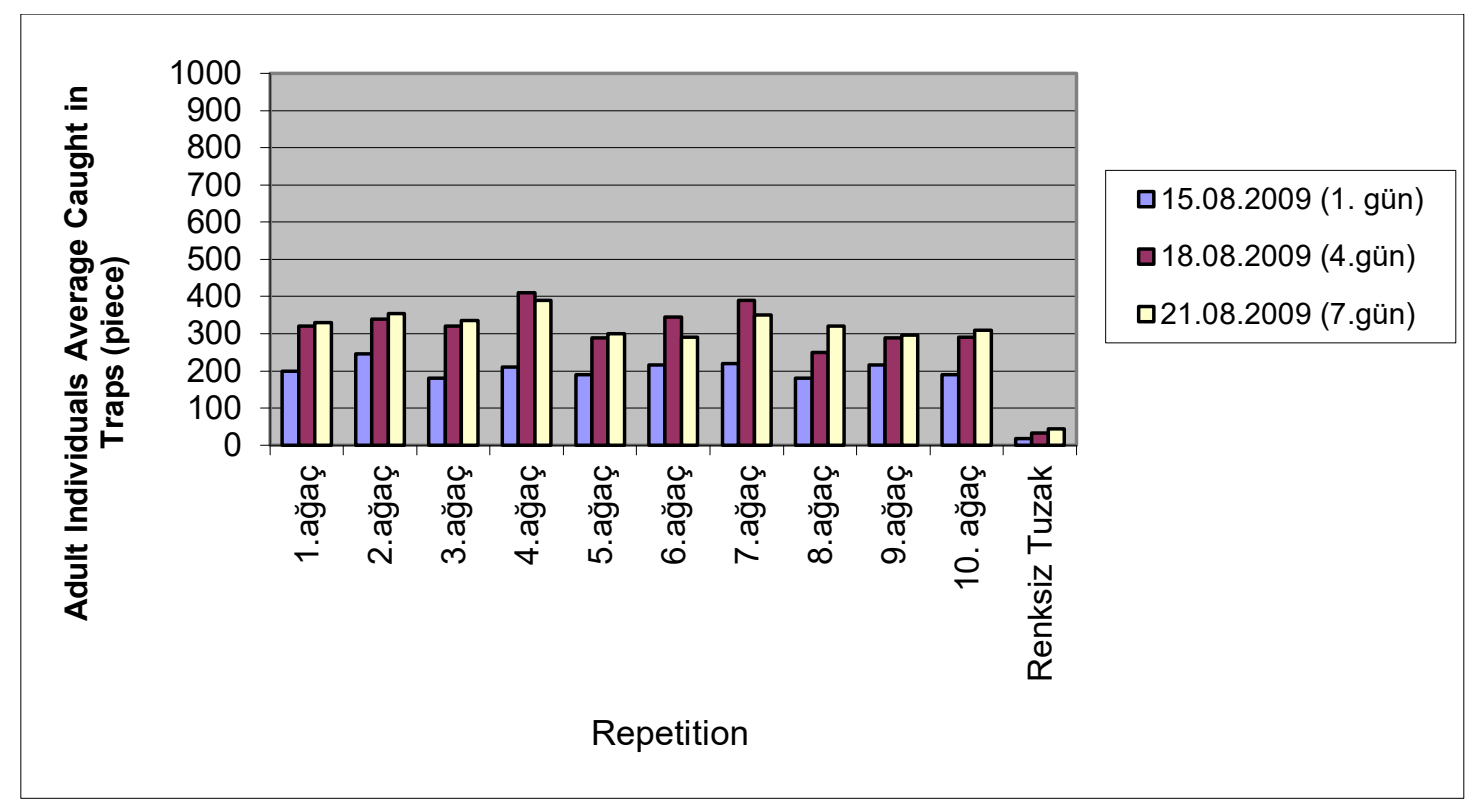

Figure 4. Number of Adult Individuals Captured on One Sticky Trap on Trees on Day $1^{\text {st }} 4^{\text {th }}$ and $7^{\text {th }}$.

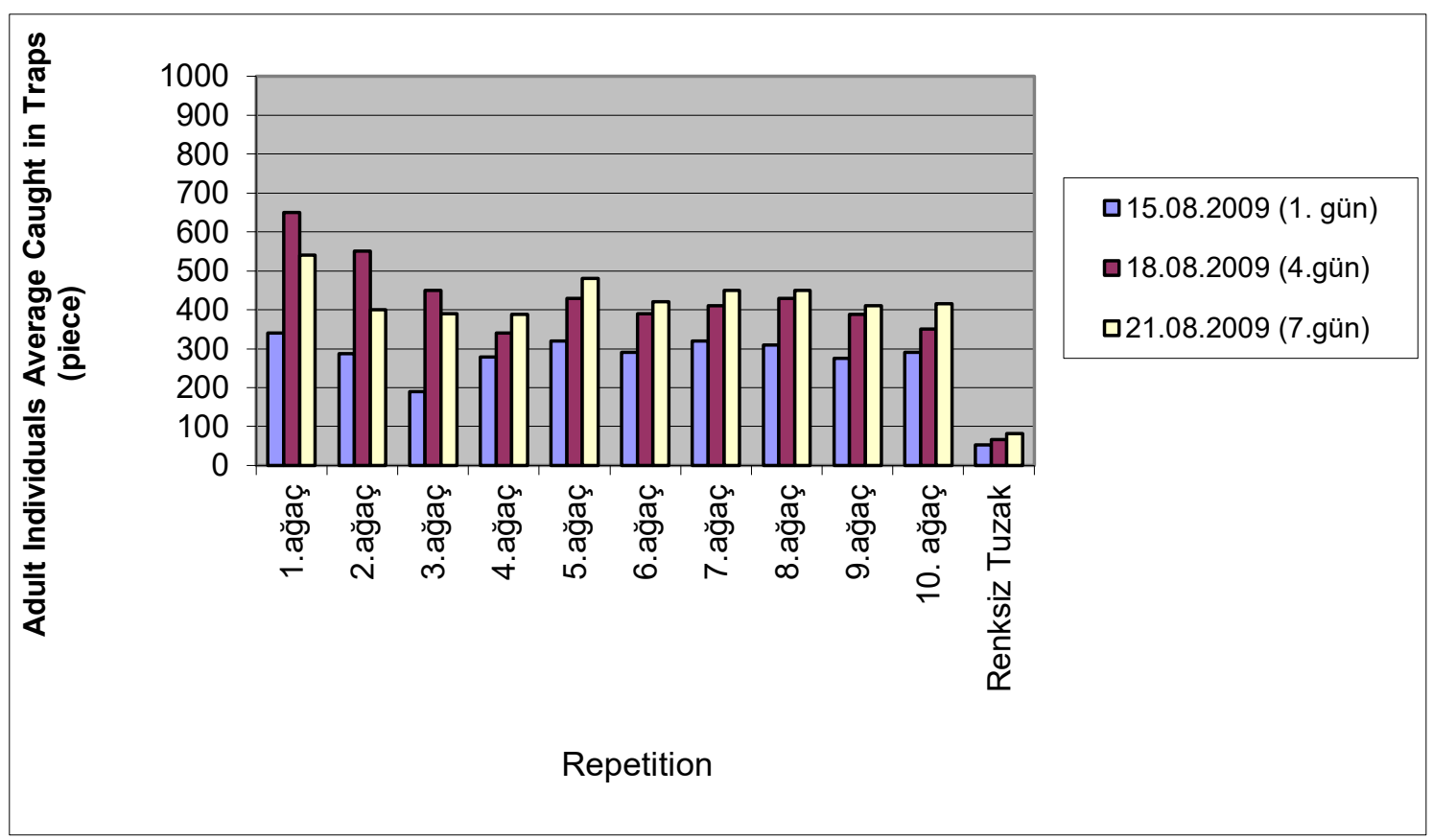

Figure 5. Number of Adult Individuals Captured on Three Sticky Traps on Trees on Day $1^{\text {st }}, 4^{\text {th }}$ and $7^{\text {th }}$. 


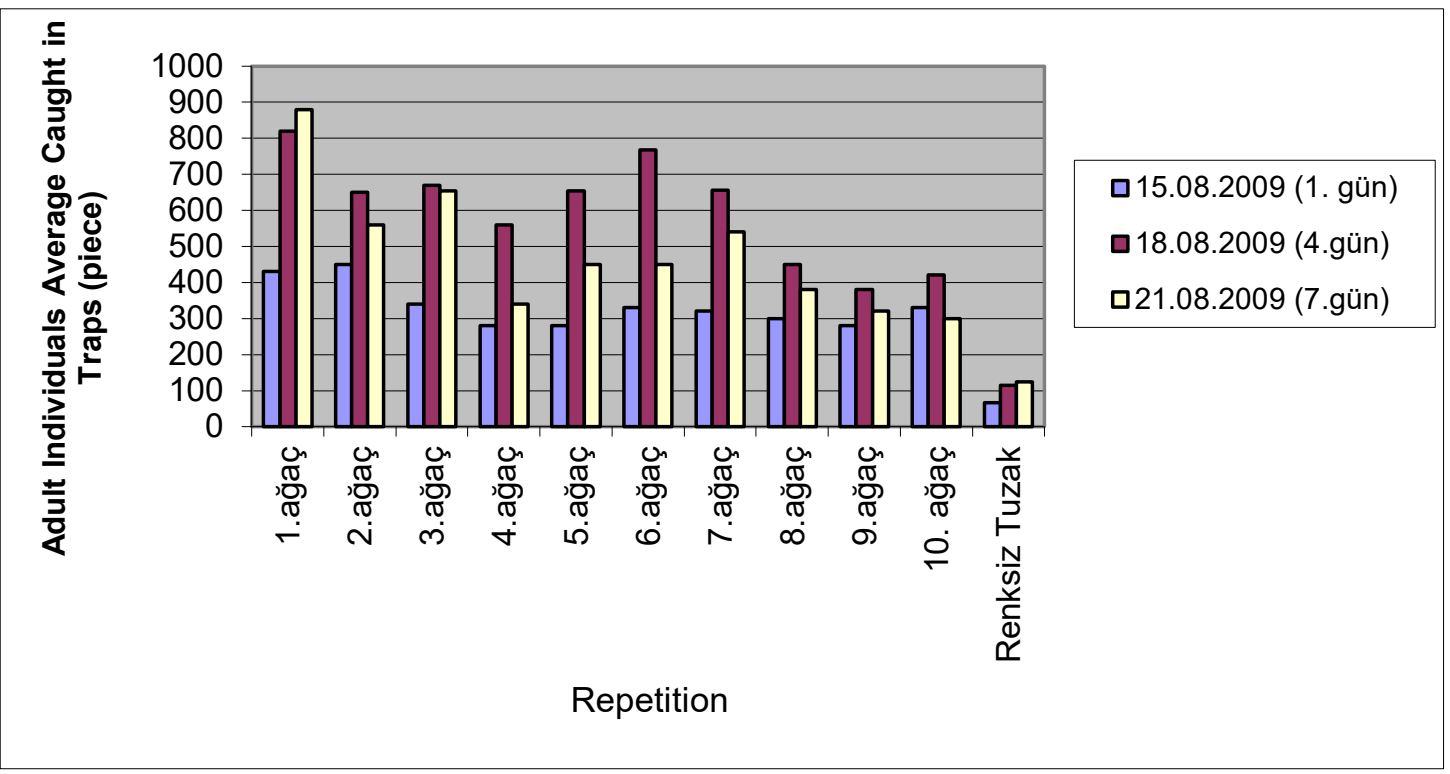

Figure 6. Number of Adult Individuals Captured on Four Sticky Traps on Trees on Day $1^{\text {st }} 4^{\text {th }}$ and $7^{\text {th }}$.

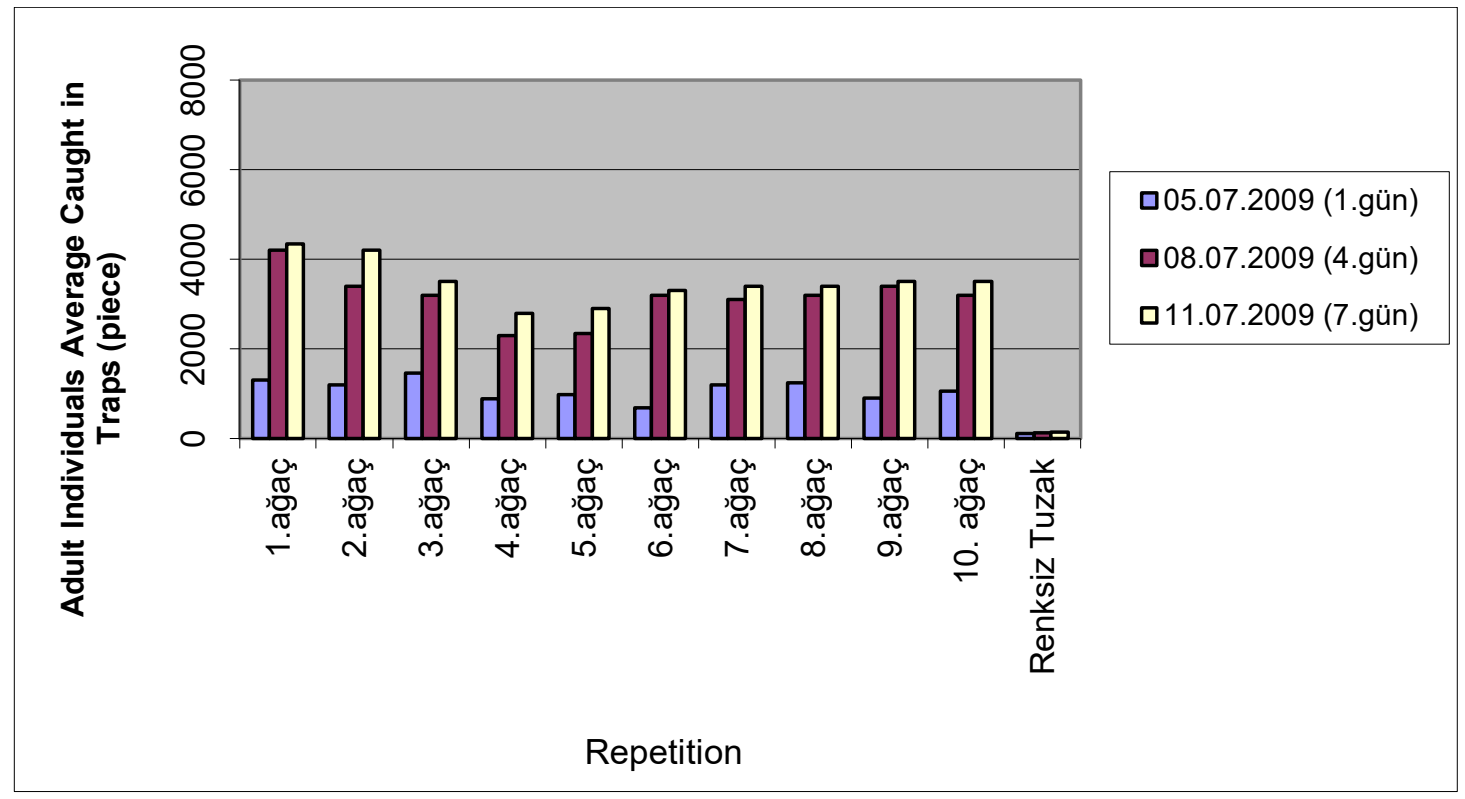

Figure 7. Number of Adult Individuals Caught on One Sticky Trap on Trees on Day $1^{\text {st }}, 4^{\text {th }}$ and $7^{\text {th }}$.

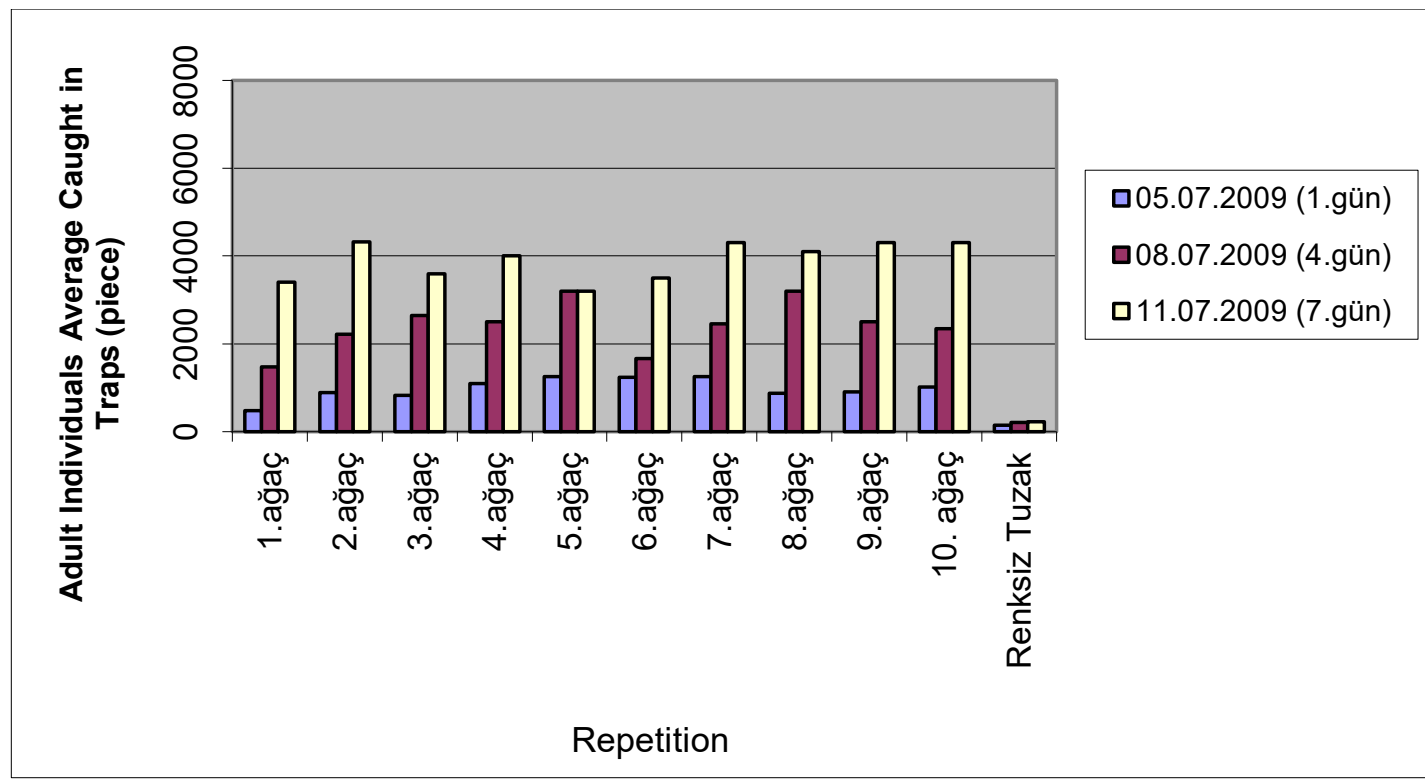

Figure 8. Number of Adult Individuals Caught on Three Sticky Traps on Trees on Day $1^{\text {st }}, 4^{\text {th }}$ and $7^{\text {th }}$. 


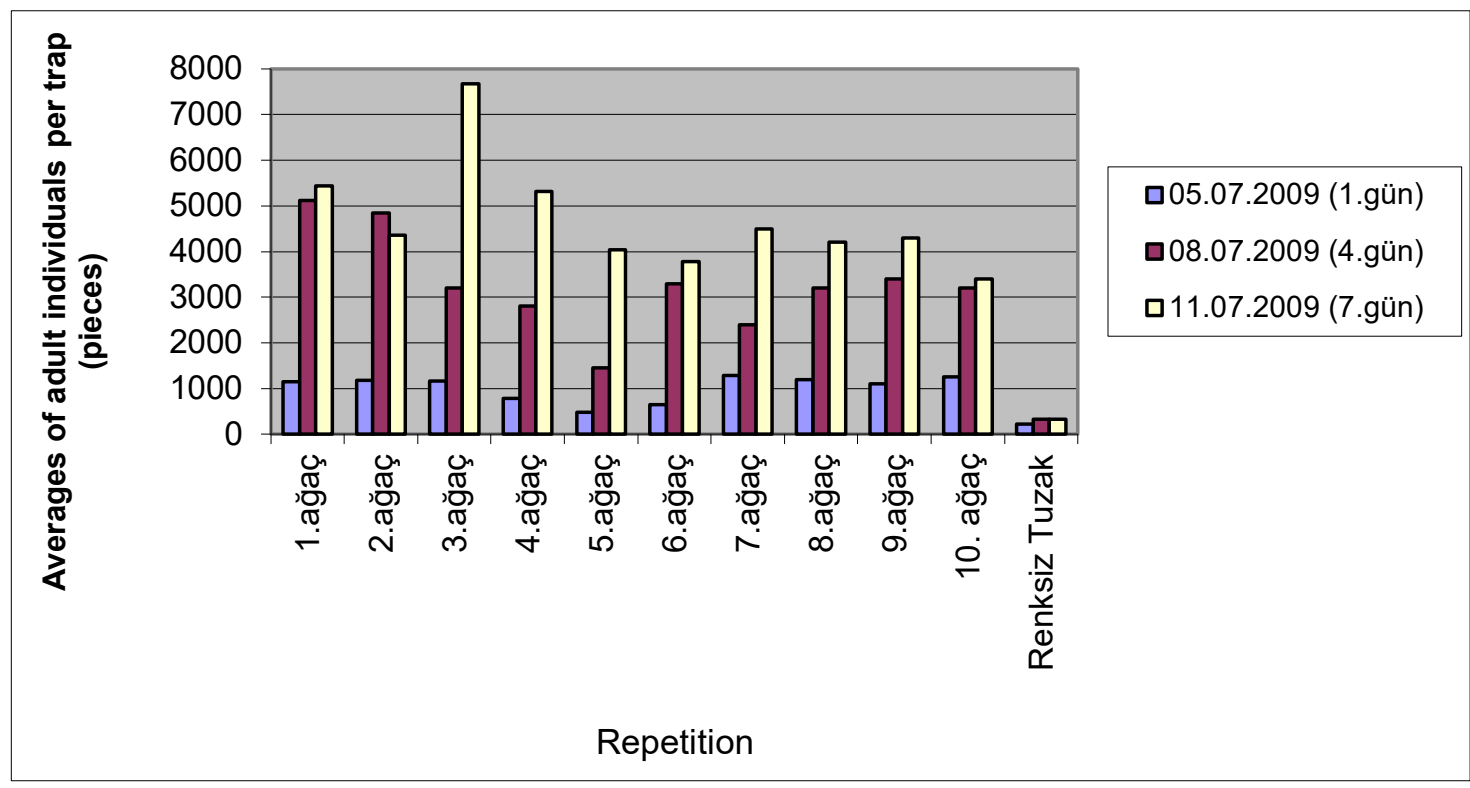

Figure 9. Number of Adult Individuals Caught on Four Sticky Traps on Trees on Day $1^{\text {st }}, 4^{\text {th }}$ and $7^{\text {th }}$.

Statistical analyses showed differences between populations (Table 3).

Table 3. Statistical Difference Between Populations.

\begin{tabular}{lrrr}
\hline B & A & & 2448,2626 \\
A & & B & 353,9596 \\
\hline
\end{tabular}

Again, statistical evaluation of the trap numbers in the study, it was found that the numbers of adult individuals captured in trees with 4 traps were different from those numbers in trees with 1 and 3 traps hung. Accordingly, numbers of adult individuals captured increased with the number of traps hung on each tree (Table 4).

Table 4. The Difference Between the Numbers of Sticky Traps on a Tree

\begin{tabular}{|c|c|c|}
\hline Trap counts & & Least Sq Mean \\
\hline Quadruple Trap A & & 1599,4545 \\
\hline Single Trap & B & 1308,2121 \\
\hline Triple Trap & B & 1295,6667 \\
\hline
\end{tabular}

In parallel with the other study, differences between the number of individuals captured increased with the increasing number of days that traps were hung, and statistically significant differences were found between the number of individuals captured in days 1, 4 and 7 (Table 5).

Table 5. Statistical Differences Between the Time of Sticky Traps to Stay on Trees.

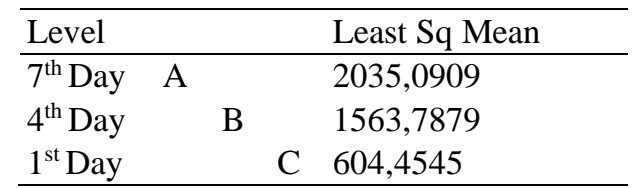

\subsubsection{Determining the Effects of Sticky Traps in Different Populations in Different Numbers (1, 3, and 4) with Wedge Impact Method and Nymph Counting Method}

In this study however, whether or not reduction in population could be achieved was investigated based on counts of adults and leaves with wedge impact method and nymph counts with the purpose of determining the effects of traps on adult and nymph populations on 4 different populations based on adult and nymph counts of psylla.

\section{Studies by Sticky 1 (one) trap}

\section{a. Population A}

Mean numbers of adult individuals captured with wedge impact method after counts on days 1, 4 and 7 when the adult population reached the range between $\mathbf{2 4}$ and $\mathbf{3 2}$ in population follow-up in trees are given in Figure 10.

\section{b. Population B}

Counts of nymphs achieved in days 1, 4 and 7 after hanging 1 trap per tree after the mean nymph count on 10 compound leaves reached 13 and 16 nymphs in population follow-up on trees are given in Figure 11.

\section{c. Population C}

Counts of adult individuals achieved in days 1, 4 and 7 per tree obtained with wedge impact method after reaching adult population reached the range between $\underline{\mathbf{3 5} \text { and } \mathbf{4 1}}$ are given in Figure 12.

\section{d. Population D}

Counts of nymphs achieved in days 1, 4 and 7 after hanging 1 trap per tree after the mean nymph count on 10

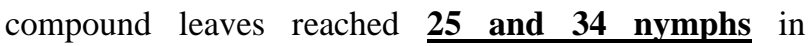
population follow-up on trees are given in Figure 13. 


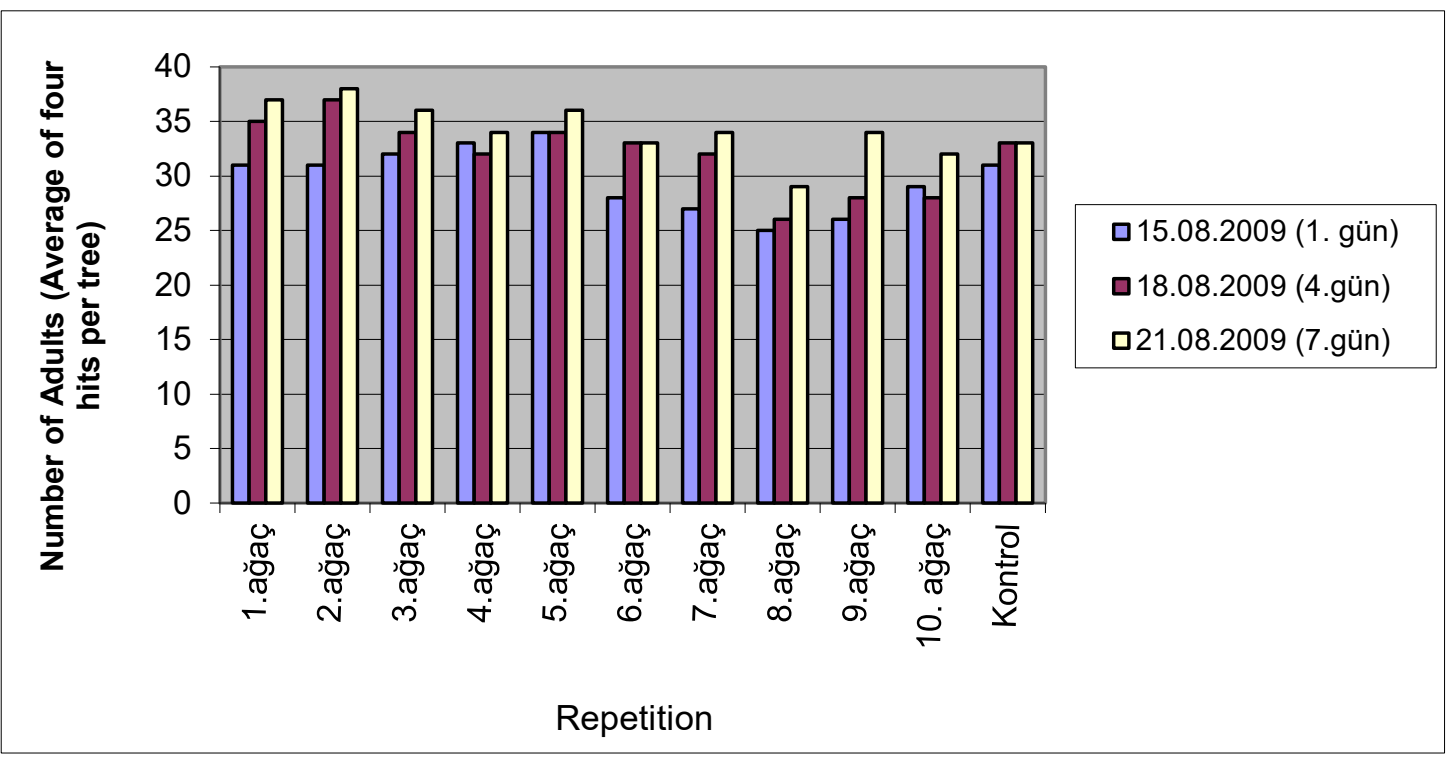

Figure 10. The effects of 1 (One) hang trap application per tree on adult population fluctuation of Agonescena pistaciae (between 24-32 adults) on days $1^{\text {st }}, 4^{\text {th }}$ and $7^{\text {th }}$.

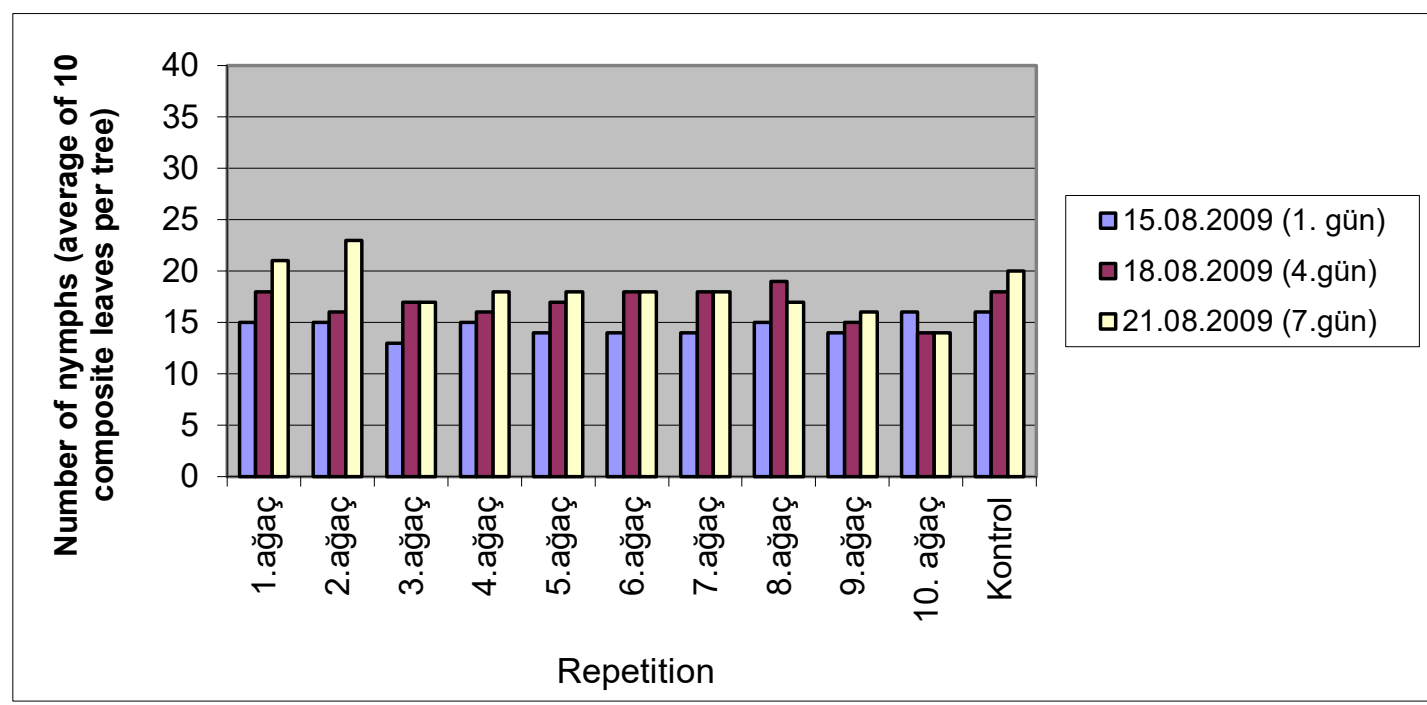

Figure 11. The effects of 1 (One) hang trap application per tree on nymph population fluctuation of Agonescena pistaciae (between 1316 nymph) on days $1^{\text {st }}, 4^{\text {th }}$ and $7^{\text {th }}$.

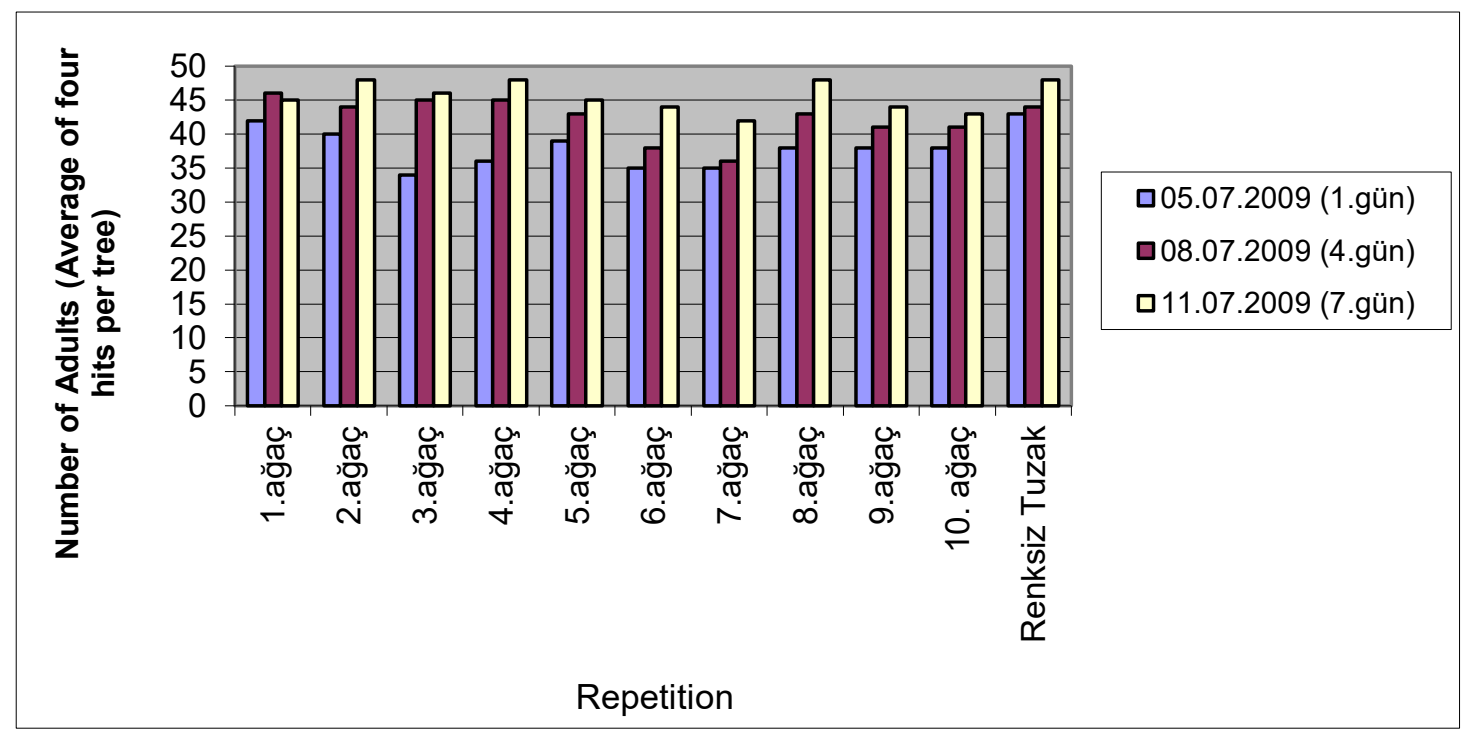

Figure 12. The effects of 1 (One) hang trap application per tree on adult population fluctuation of Agonescena pistaciae (between 35-41 adults) on days $1^{\text {st }}, 4^{\text {th }}$ and $7^{\text {th }}$. 


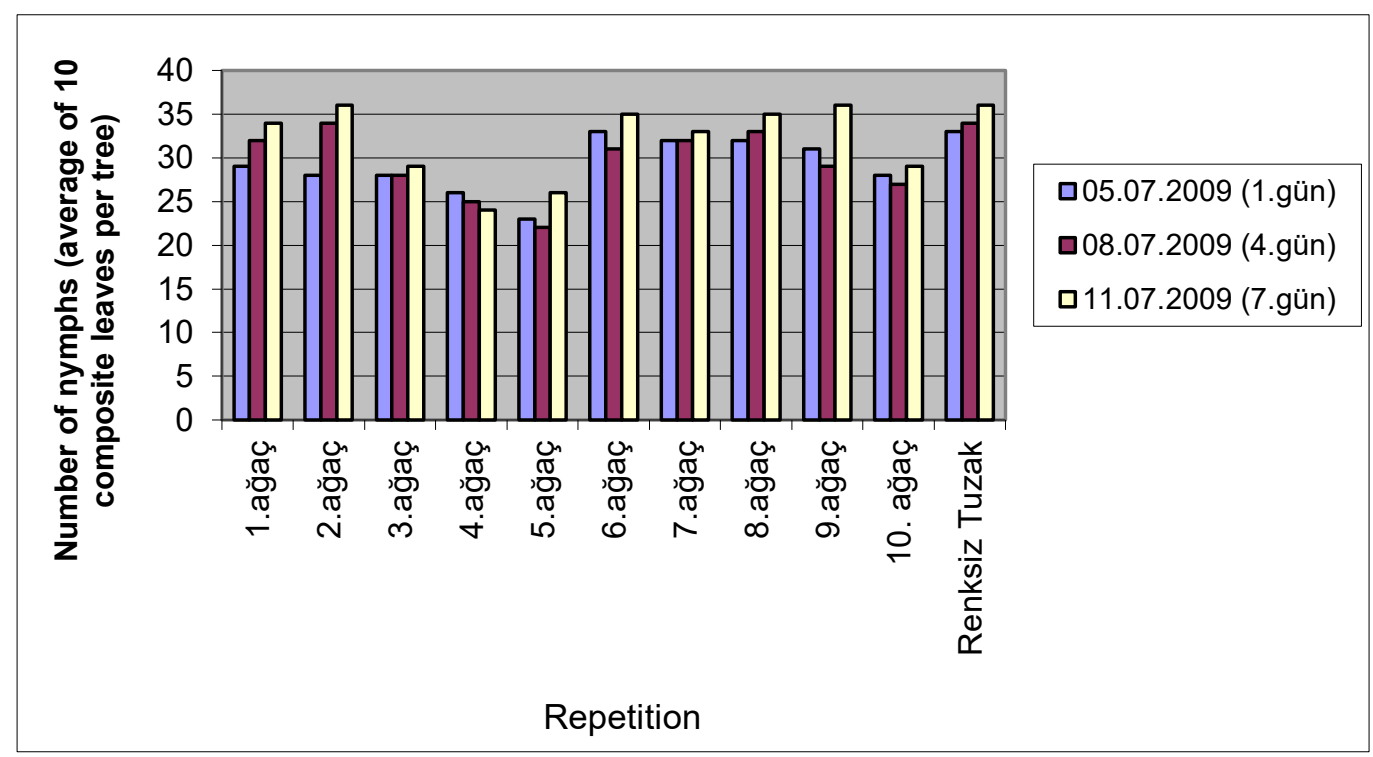

Figure 13. The effects of 1 (One) hang trap application per tree on nymph population fluctuation of Agonescena pistaciae (between 2534 nymph) on days $1^{\text {st }}, 4^{\text {th }}$ and $7^{\text {th }}$.

\section{Study with 3 Sticky traps}

\section{a. Population A}

Counts of adult individuals achieved in days 1, 4 and 7 with three traps per tree obtained with wedge impact method after reaching adult population reached the range between $\underline{\mathbf{2 8} \text { and } \mathbf{3 3}}$ are given in Figure 14.

\section{b. Population B}

Counts of nymph individuals achieved in days 1, 4 and 7 with three traps per tree obtained with wedge impact method after reaching adult population reached the range between $\underline{\mathbf{1 4} \text { and } \mathbf{1 5}}$ on 10 compound leaves are given in Figure 15.

\section{c. Population C}

Counts of adult individuals achieved in days 1, 4 and 7 with three traps per tree obtained with wedge impact method after reaching adult population reached the range between 40 and 45 are given in Figure 16.

\section{d. Population D}

Counts of nymphs achieved in days 1, 4 and 7 after hanging 3 traps per tree after the mean nymph count on 10 compound leaves reached $\mathbf{2 7}$ and $\mathbf{3 3}$ nymphs in population follow-up on trees are given in Figure 13.

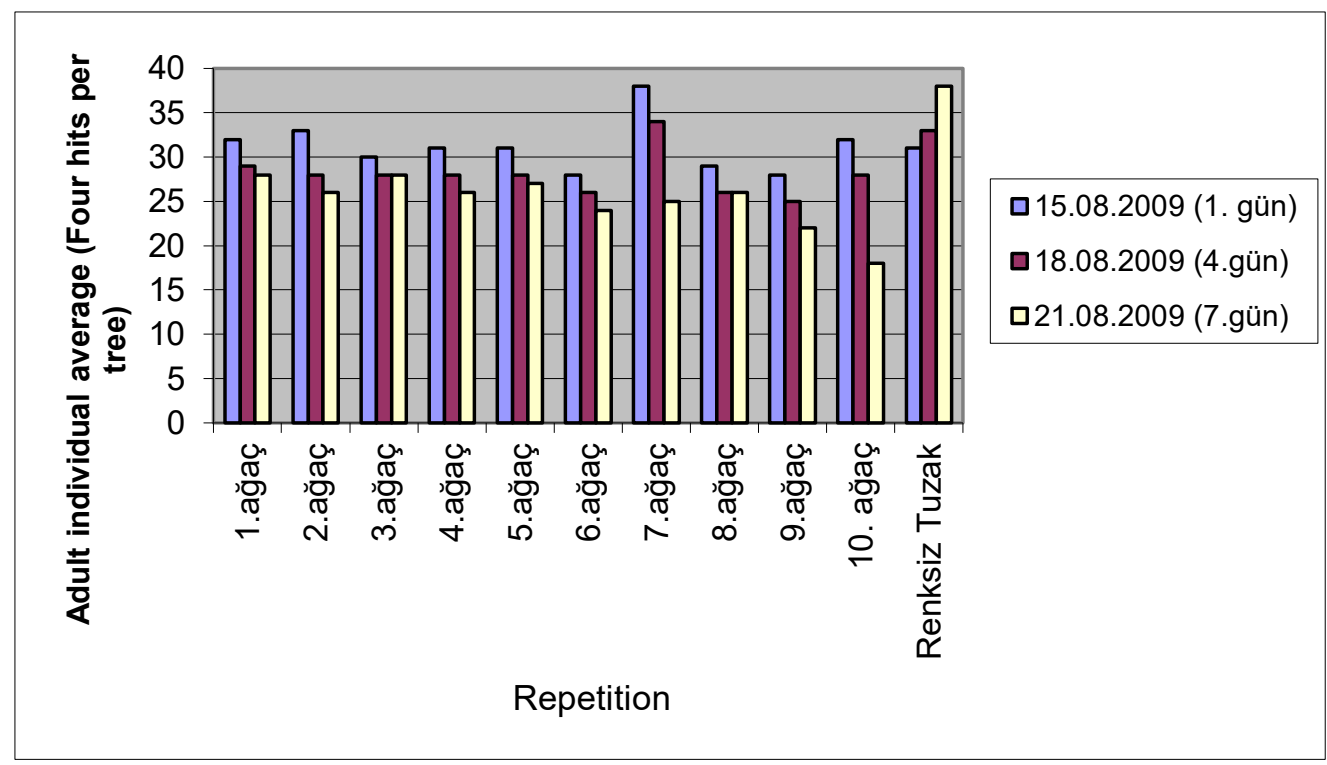

Figure 14. The effects of 3 (Three) hang trap application per tree on adult population fluctuation of Agonescena pistaciae (between 28-33 adults) on days $1^{\text {st }}, 4^{\text {th }}$ and $7^{\text {th }}$. 


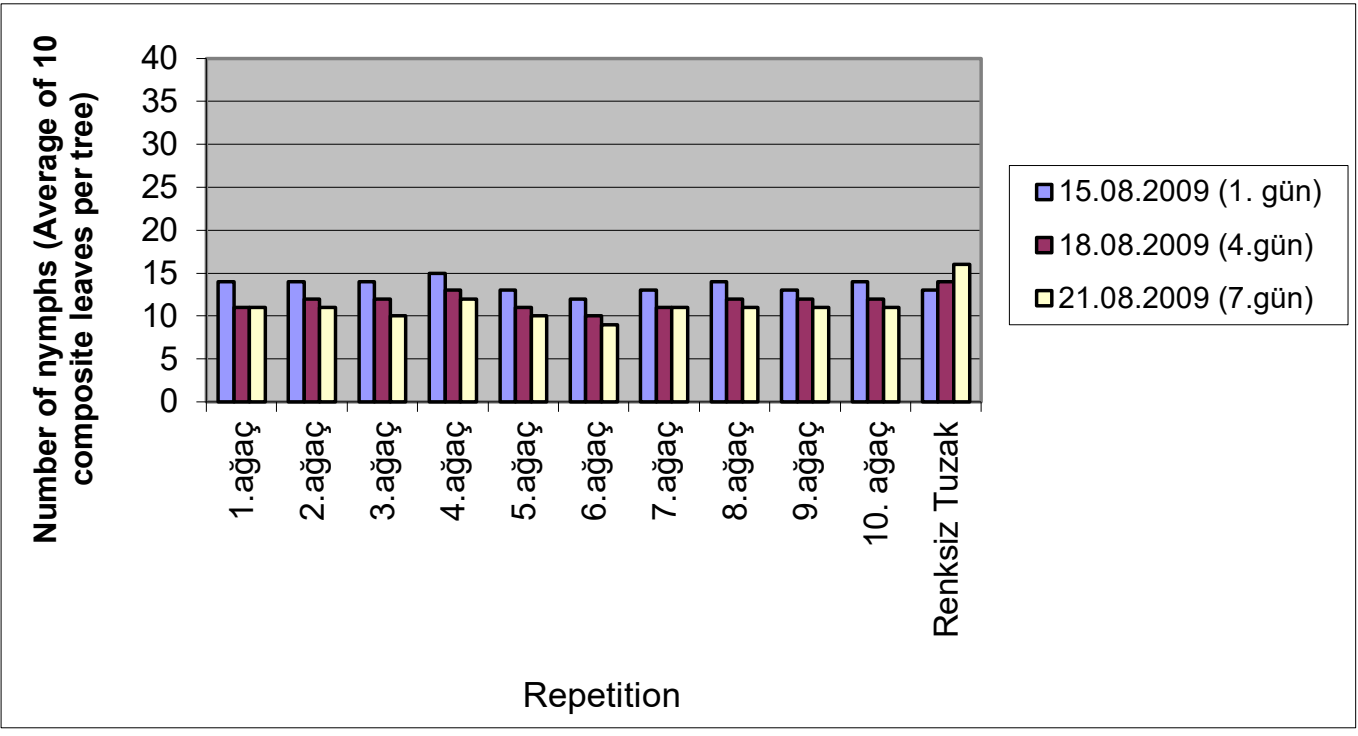

Figure 15. The effects of 3 (Three) sticky trap application per tree on nymph population fluctuation of Agonescena pistaciae (between 14-15 nymph) on days $1^{\text {st }}, 4^{\text {th }}$ and $7^{\text {th }}$.

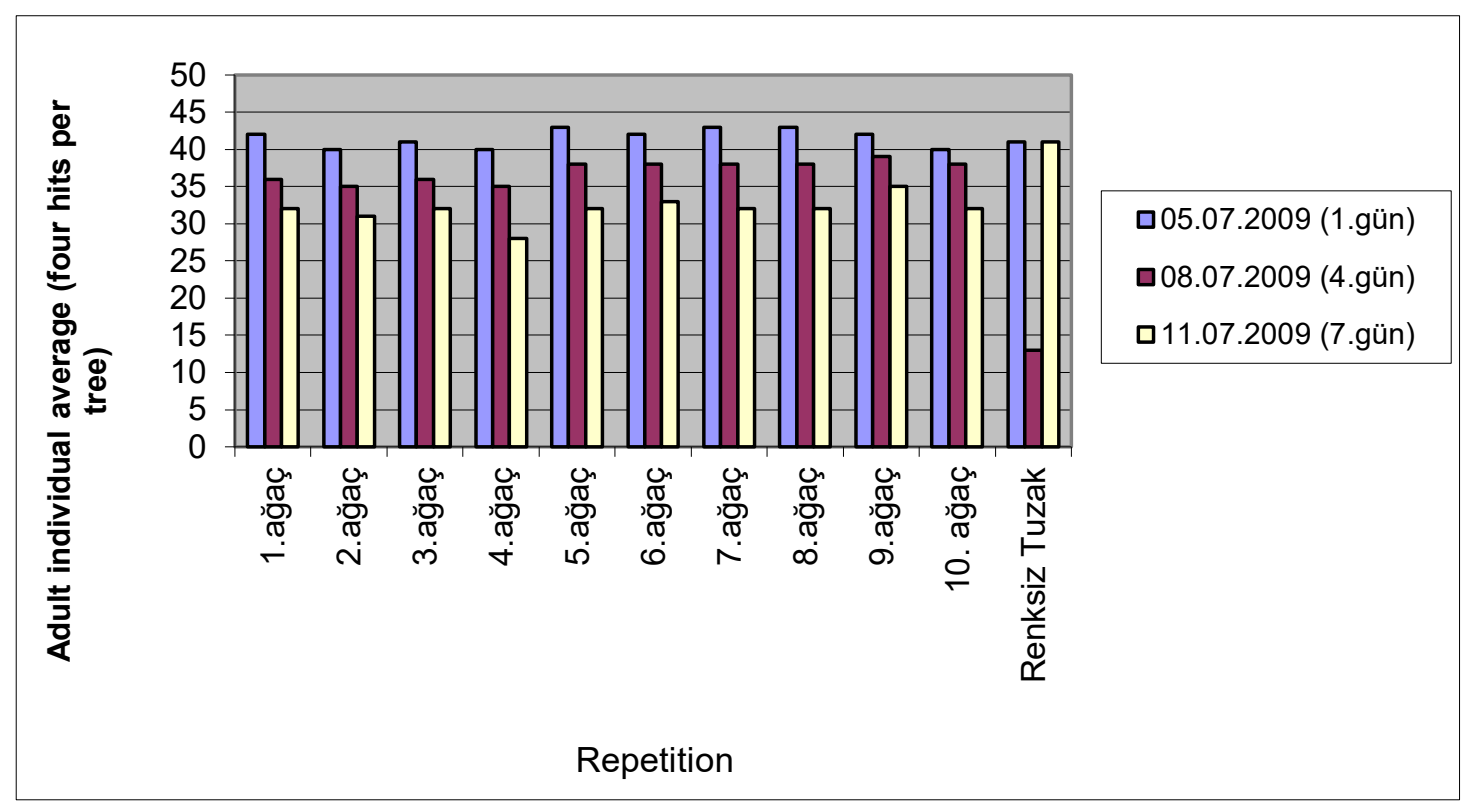

Figure 16. The effects of 3 (Three) hang trap application per tree on adult population fluctuation of Agonescena pistaciae (between 40-45 adults) on days $1^{\text {st }}, 4^{\text {th }}$ and $7^{\text {th }}$.

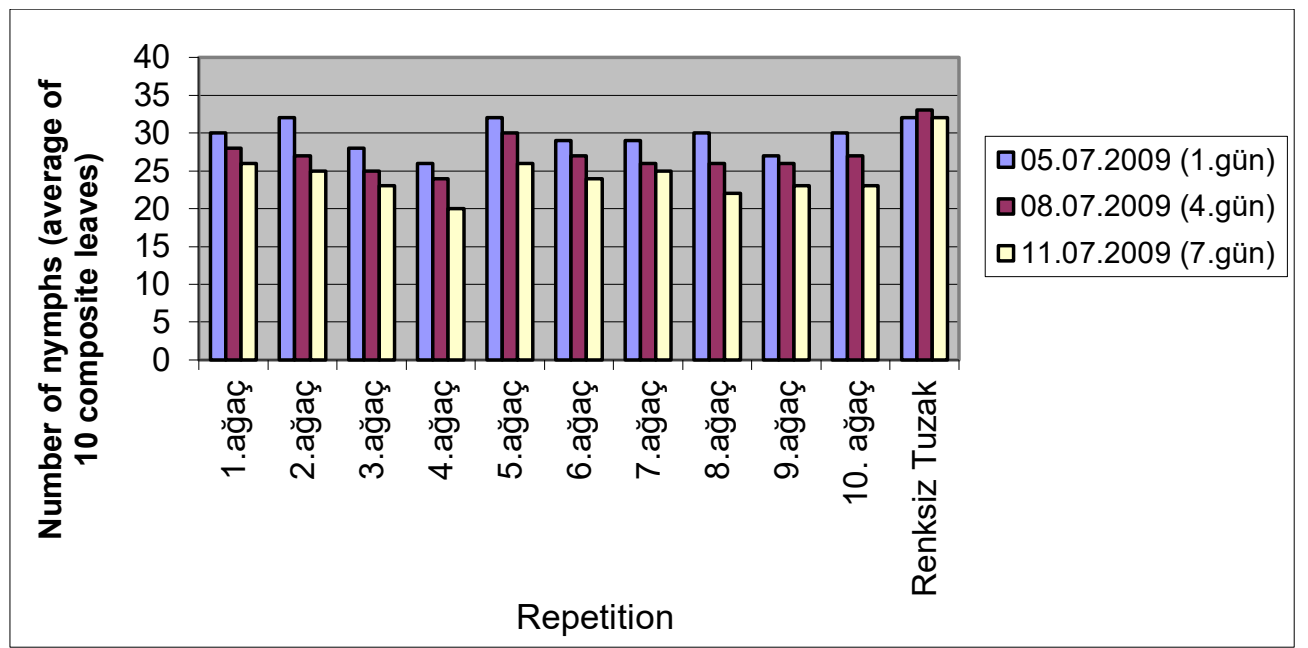

Figure 17. The effects of 3 (Three) hang trap application per tree on nymph population fluctuation of Agonescena pistaciae (between 27 33 nymph) on days $1^{\text {st }}, 4^{\text {th }}$ and $7^{\text {th }}$. 


\section{Study with 4 traps hung}

\section{a. Population A}

Counts of adult individuals achieved in days 1,4 and 7 with four traps per tree obtained with wedge impact method after the adult population reached the range between 26 and 38 are given in Figure 18.

\section{b. Population B}

Counts of nymphs achieved in days 1, 4 and 7 after hanging 4 traps per tree after the mean nymph count on 10 compound leaves reached 13 and 17 nymphs_in population follow-up on trees are given in Figure 19.

\section{c. Population $\mathrm{C}$}

Counts of adult individuals achieved in days 1, 4 and 7 with four traps per tree obtained with wedge impact method after the adult population reached the range between 36 and 46 are given in Figure 20.

\section{d. Population D}

Counts of nymphs achieved in days 1, 4 and 7 after hanging 4 traps per tree after the mean nymph count on 10 compound leaves reached 28 and 37 nymphs_in population follow-up on trees are given in Figure 21.

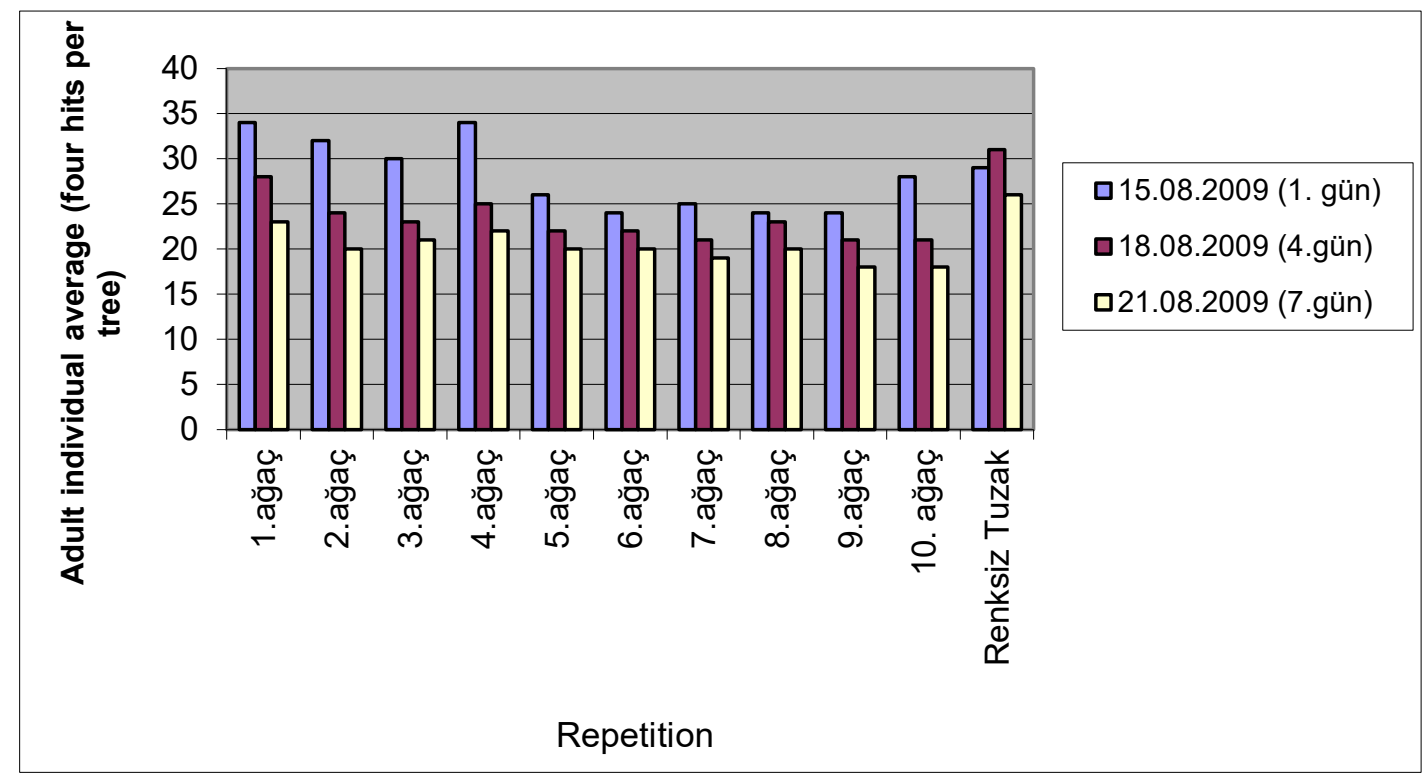

Figure 18. The effects of 4 (Four) hang trap application per tree on adult population fluctuation of Agonescena pistaciae (between 26-38 adults) on days $1^{\text {st }}, 4^{\text {th }}$ and $7^{\text {th }}$.

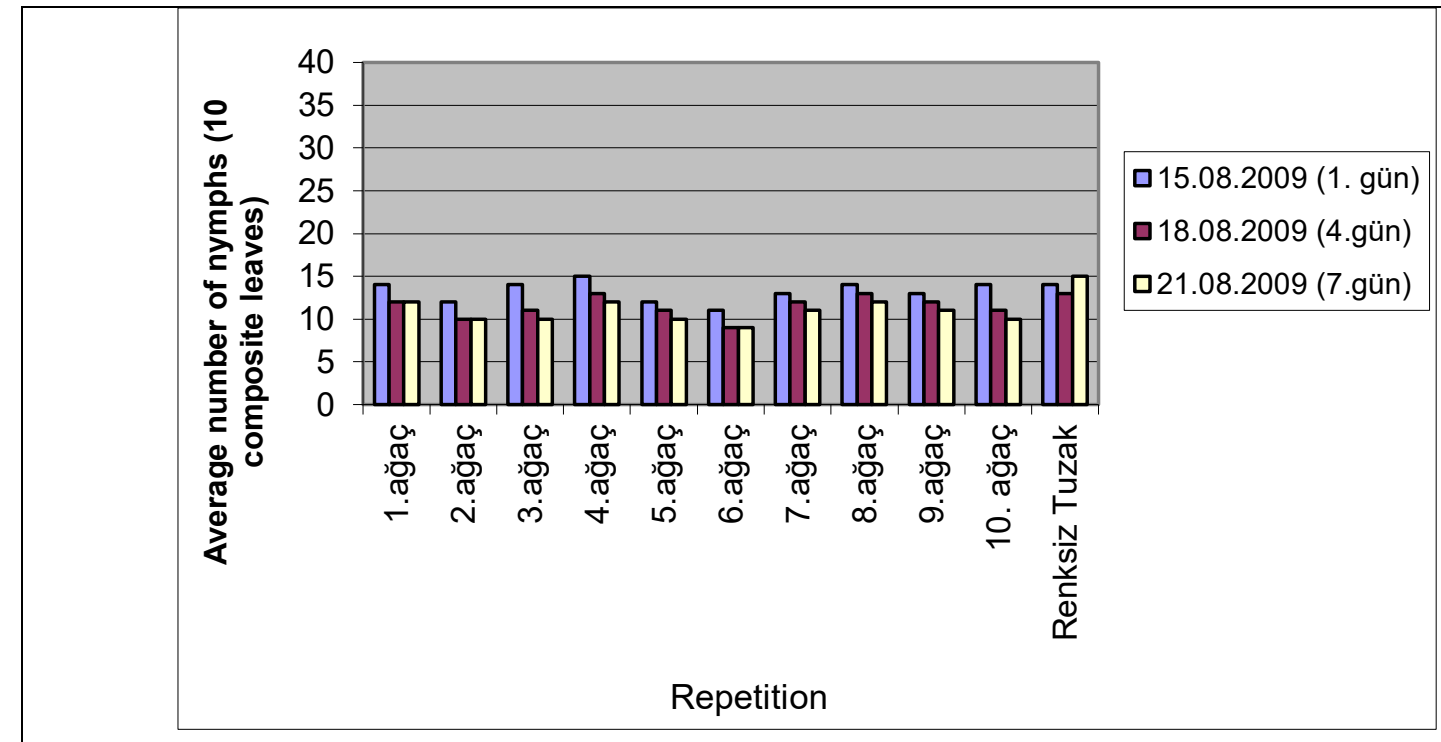

Figure 19. The effects of 4 (Four) hang trap application per tree on nymph population fluctuation of Agonescena pistaciae (between 1317 nymph) on days $1^{\text {st }}, 4^{\text {th }}$ and $7^{\text {th }}$. 


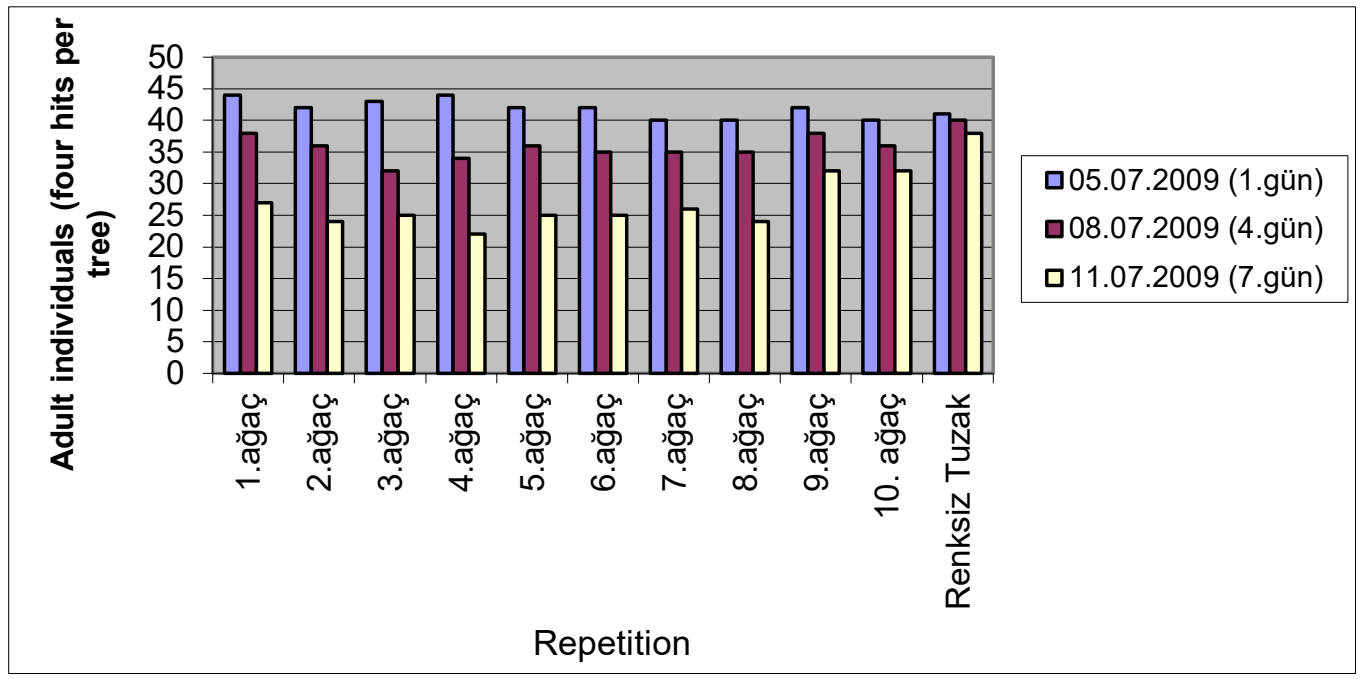

Figure 20. The effects of 4 (Four) hang trap application per tree on adult population fluctuation of Agonescena pistaciae (between 38-46 adults) on days $1^{\text {st }}, 4^{\text {th }}$ and $7^{\text {th }}$.

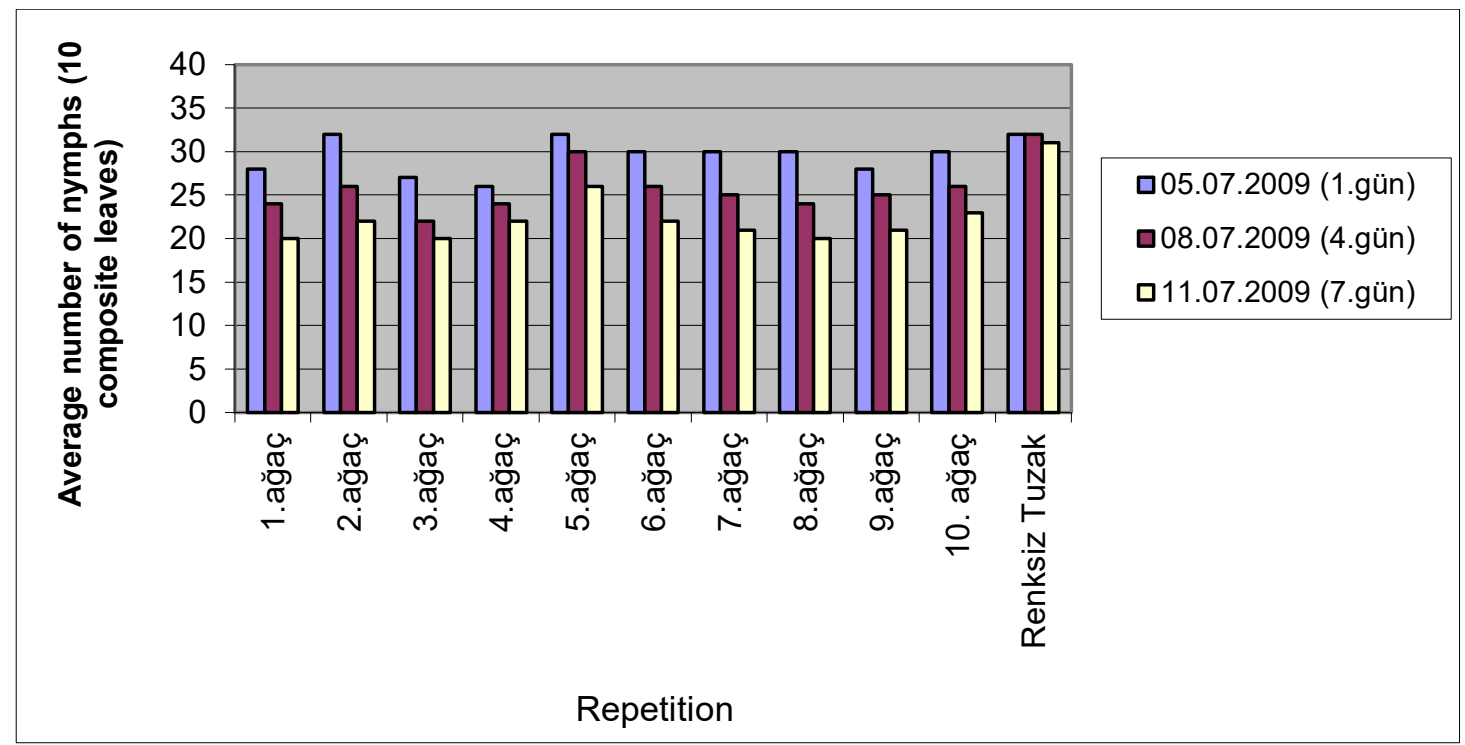

Figure 21. The effects of 4 (Four) hang trap application per tree on nymph population fluctuation of Agonescena pistaciae (between 2837 nymph) on days $1^{\text {st }}, 4^{\text {th }}$ and $7^{\text {th }}$.

\section{Discussion}

Statistical analyses were performed in order to determine whether or not there are any differences between populations based on trap numbers, that is, whether or not the population increases or decreases with the increases in trap numbers and to determine whether or not number of traps affects the population size based on population type (adult or nymph) and based on increases in number of individuals in the population. The $\mathrm{R}^{2}$ value was found as 85 in the analyses, and CV was 14 . Results of analyses are given in Tables 10, 11 and 12.

No differences regarding densities were found between populations arising from hanging of traps. That is, the number of traps hung created reduction in populations in the same percentage whatever the density is (Table 10).
Table 10. Differences According to Population Densities.

\begin{tabular}{lll}
\hline Populations & & Least Sq Mean \\
\hline A & A &. \\
B & A &. \\
C & A &. \\
D & A &. \\
\hline
\end{tabular}

Counting the population in adults or nymphs did not create any differences in populations. There was parallelism between the adult and nymph counts on trees. Parallel results were obtained in nymph and adult trials whatever the number of traps hung were, showing the reliability of the studies (Table 11). 
Table 11. Differences in Types of Populations (Biological Period)

\begin{tabular}{lll}
\hline Level & & Least Sq Mean \\
\hline Adult & A & \\
Nymph & A & \\
\hline
\end{tabular}

One of the significant assessments of the study involves the results created by the number of traps on populations. Based on the results of the study, populations tended to be higher in trees with 1 trap as compared to trees with 3 or 4 traps. Populations decreased with increasing numbers of traps, and results of this study were in parallel with the adult counts in traps. The adult population captured increased with the increasing number of traps, and this rate affected the nymph/adult populations on trees in different numbers (populations A, B, C and D) and populations decreased (Table 12). Again, as seen in the Table 12 below, different groups were obtained in trees with 3 or 4 traps hung.

Table 12. Evaluation of sticky trap numbers in terms of populations.

\begin{tabular}{|c|c|c|c|}
\hline Level & & & Least Sq Mean \\
\hline 1 & A & & 30,227273 \\
\hline 3 & B & & 26,060606 \\
\hline 4 & & $\mathrm{C}$ & 24,280303 \\
\hline
\end{tabular}

In analyses aiming at determining if there are any differences between populations in the numbers of nymphs and adults, it was found that there were differences between the controls and other applications (Table 13).

Table 13. Populations in terms of nymphs and adults

\begin{tabular}{lllll}
\hline Level & & & & Least Sq Mean \\
\hline 11 & A & & & 29,666667 \\
1 & A & B & & 28,000000 \\
2 & & B & C & 27,611111 \\
5 & & B & C & 26,777778 \\
7 & & B & C & 26,555556 \\
8 & & B & C & 26,333333 \\
3 & & & C & 26,222222 \\
4 & & & C & 26,194444 \\
9 & & & C & 26,111111 \\
6 & & & C & 26,027778 \\
10 & & & C & 25,916667 \\
\hline
\end{tabular}

Acknowledgement: We are honored to submit our thanks to Daniel BUCKARD (Switzerland) for the identification of the species belonging to the Psyllidae family and to Republic of Turkey Ministry of Agriculture and Forestry General Directorate of Agricultural Research and Policies (TAGEM) for project support.

\section{References}

Altın, M., A. Yücel, H. Bolu, 1992. Güneydoğu Anadolu Projesi (GAP) Bölgesi Antepfıstığı Alanlarında Entegre Mücadele
Çalışmaları Öncesinde Zirai Mücadelenin Gerçek Durumu, Karşılaşılan Sorunlar ve Çözüm Yolları. Uluslararası Entegre Mücadele Sempozyumu Bildirileri, 15-17 Ekim, İZMIR, S. 87-95.

Altın, M., Bolu, H. ve C. Kaplan, 1996. Güneydoğu Anadolu Bölgesi Antepfistığı (Pistacia vera L.) Alanlarında Önemli Bazı Zararlı ve Yararlı Türlerin Populasyon Değişimlerinin Belirlenmesi Üzerinde Araştırmalar. Tarım ve Köy İşleri Bakanlığı Tarımsal Araştırmalar Genel Müdürlüğü Yayınları Sonuç Raporu. Proje Kod No: BK/96/06/09/504.25 s.

Bolu, H., 2002. Güneydoğu Anadolu Bölgesi Antepfistığı Alanlarındaki Böcek ve Akar Faunası Üzerinde Araştırmalar. Türk. entomol. derg., 2002, 26 (3): 197-208.

Özgen, İ., Ayaz, T., Mutlu, Ç. and H. Bolu, 2013. The Capture Effects of Yellow Stick Traps in the Different Wavelengths to the Adults of Agonescena pistaciae Burc. \& Laut. (Hemiptera: Psyllidae) from Turkey. Mun. Ent. Zool. 8 (1): 486-492.

Hadian, A.R. and H. Seyedoleslami, 2001. Effiency of Yellow Sticky Board Traps and Limb Jarring in the Capture of Adult Pistachio Psylla Agonescena pistaciae burkhardt \& Lauterer (Hom: Psyllidae). J. Sci. \& Technol. Agric. \& Natur. Resour., Vol 6. No:2.

Hirota, T., and Y. Kato, 2001, influence of visual stimuli on host location in the butterfly, Eurema hecabe. Entomologia Experimentalis et Applicata 101:199-206 